\title{
NPRL2 wt Allele
}

National Cancer Institute

\section{Source}

National Cancer Institute. NPRL2 wt Allele. NCI Thesaurus. Code C63530.

Human NPRL2 wild-type allele is located in the vicinity of 3p21.31 and is approximately 4 $\mathrm{kb}$ in length. This allele, which encodes GAT OR complex protein NPRL2, plays a role in growth suppression and may be involved in tumor suppression for multiple cancers. 